\title{
Rejuvenation of a 100 yr old giant sequoia (Sequoiadendron giganteum Buchholz) through in vitro meristem culture
}

\author{
O. Monteuuis and M.C. Bon
}

Association Forêt Cellulose (AFOCEL), Domaine-de-l'Etançon, 77370 Nangis, France

\section{Introduction}

Vegetative propagation is currently recognized as a powerful tool for forest tree improvement to increase forest plantation yield (Zobel and Talbert, 1984). However, selected trees - the ortets - must develop enough to reach a sufficient size for reliable evaluation of their genetic potential, which is accompanied in most cases by a significant decrease of their capacities for cloning by asexual propagation methods. In this context, the possibilities of cloning selected mature tree genotypes true-to-type remain greatly influenced by the prior rejuvenation of the ortets. This problem was investigated at AFOCEL using Sequoiadendron giganteum Buchholz.

\section{Materials and Methods}

\section{Plant material}

The mature material originated from a $100 \mathrm{yr}$ old Sequoiadendron giganteum selected in situ. The easy-to-root juvenile clone used as the control consisted of young cuttings derived from a 2 yr old seedling.

\section{Experimental methods}

The mature and the juvenile materials were concurrently compared regarding their respective capacities for vegetative propagation, using propagation by cuttings, grafting and subsequently in vitro methods. These included subcultures with sequential BAP (benzylaminopurine) treatments (Fouret et al., 1986), micrografting (Monteuuis, 1987a) and meristem culture (Monteuuis, 1987b, 1988). Rejuvenation of the mature material was evaluated through morphological - especially leaf form - and organogenic capacity criteria, with reference to known juvenile material. In addition, these observations were supported by biochemical investigations (Bon, 1988).

\section{Results}

Under nursery conditions, the mature material failed to root, while the juvenile clone rooted but rooting ability denoted seasonal variations. Moreover, it was shown that leaf form may be a reliable marker for rooting (Monteuuis, 1985). The rejuvenation of the apical meristem of the scion resulting from grafting onto a young seedling and expressed through a morphological juvenile type reversion, was shortlived and did not induce any improve- 


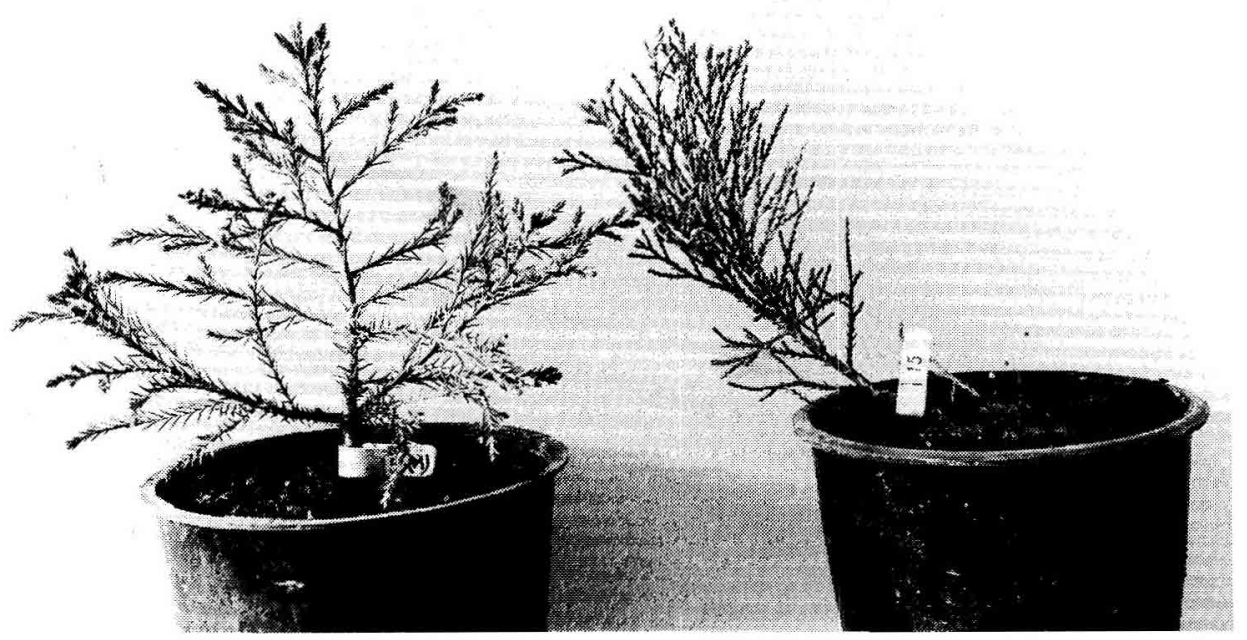

Fig. 1. Rejuvenation of a $100 \mathrm{yr}$ old giant sequoia through in vitro meristem culture. On the left: rejuvenated rooted cutting originating from meristem culture. On the right: the same $100 \mathrm{yr}$ old clone non-rejuvenated by grafting.

ment of the rooting ability of the mature material. Similarly, despite using scions as small as $200-300 \mu \mathrm{m}$, rejuvenation attempts through in vitro micrografting led to only temporary rejuvenation (Monteuuis, 1987a). Nevertheless, the fleeting morphological rejuvenation corresponded with the meristem protein pattern associated with juvenile material (Bon and Monteuuis, 1987).

Subcultures of microcuttings using BAP treatments appeared to be less effective than for other species (Fouret et al., 1985). Morphological and organogenic observations conducted over a 3 yr period showed that in vitro medium macronutrients and, more particularly, the physiological state of the explant caused variations even under stable environmental conditions (Monteuuis and Bon, 1986; Monteuuis et al. 1987). Taking into account this physiological parameter susceptible of fluctuating greatly under outdoor conditions (Monteuuis and Gen- draud, 1987) proved to be determinant in ensuring successful meristem culture of the mature material. Thus, when removing the meristems at bud-break, it was possible to regenerate a truly rejuvenated line. The rejuvenated plantlets exhibited the same morphological characteristics and organogenic potentialities, including rooting abilities, as the juvenile clone. This rejuvenation has been maintained for more than $2 \mathrm{y} / \mathrm{r}$ for in vitro as well as for outdoor cultivated rooted cuttings. In addition, the rejuvenated material produced a $16 \mathrm{kDa}$ protein found in juvenile Sequoiadendron giganteum (Bon, 1988).

\section{Discussion and Conclusion}

For giant sequoia, like most forest tree species that do not sprout from stumps, the only possibility indeed to clone selected mature trees is to rejuvenate them 
through manipulations of ramets taken from the crown. In this context, propagators must be aware of the very promising potentialities of shoot apical meristems, which may theorically be capable of totipotency (Margara, 1982), although some specialists state that irreversible maturation processes occur within apical meristems of aborescent species in proportion to the number of mitotic divisions their cells undergo (Fortanier and Jonkers, 1976).

Our results, based concurrently on physiological, biochemical, histocytological, organogenic and morphological investigations (Bon, 1988; Monteuuis, 1988), support the hypothesis that shoot apical meristems of trees should be able to express, according to a reiterative pattern, juvenile potentialities during a period that shortens with increasing ontogenic development, the maximum intensity corresponding to bud-break. This opinion is in total accordance with Krenke's (1940) conception of maturation, although this juvenile state remains invisible most of the time, probably as a consequence of the inhibitory correlative systems. But it should be noted, as reported by Edelin (1987) that, in certain cases, meristems do not need to be excised from the mature ortet in order to develop ontogenetical reversions exhibiting the juvenile traits that characterize the first phases of ontogeny.

In contrast to the truly rejuvenated plants obtained from meristem culture, the ephemeral morphological rejuvenation induced by micrografting (Monteuuis, 1987) could be interpreted as a simple and temporary transfer of hypothetical rejuvenating substances from the juvenile tissues of the seedling rootstock to the mature scion meristem, rather than a selfjuvenile-status functioning.

As a concluding remark, it should be added that Sequoiadendron giganteum, due to its specific characteristics including foliar dimorphism that reflects the juvenility degree of its apical meristems, appears to be a good model for the study of phase change phenomena of forest trees. In this way, most of the investigation procedures, and especially biochemical techniques (Bon, 1988), proven to be powerful analytical tools for giant sequoia, are actually being applied at AFOCEL to other promising forest species in order to enhance their ability for true-to-type cloning.

\section{References}

Bon M.C. (1988) Aspects biochimiques du clonage de séquoias géants jeunes et âgés. Ph.D. Thesis Université Blaise-Pascal, ClermontFerrand. France

Bon M.C. \& Monteuuis O. (1987) Application de la technique micro 2 D PAGE au microgreffage de Sequoiadendron giganteum Buchholz. C.R.

Acad. Sci. Paris Ser. III 224, 667-670

Edelin C. (1987) Oral communication La Réitération adaptive': Phénomènes de réitération chez les végétaux ligneux Grenoble, France, 24 September 1987

Fortanier E.J. \& Jonkers H. (1976) Juvenility and maturity of plants influenced by their ontogenetical and physiological ageing. Acta Hortic. $56,37-44$

Fouret Y., Arnaud Y. \& Larrieu C. (1985) Rajeunissement in vitro du Sequoia sempervirens. Ann. AFOCEL 1984 112-137

Fouret Y., Arnaud Y. \& Larrieu C. \& Miginiac E. (1986) Sequoia sempervirens as an in vitro rejuvenation model. New Zealand J. For. Sci. $16,319-327$

Krenke W.P. (1940) The theory of the cycle of senescence and rejuvenation of plants and its practical application. Plant Breed. Abstr. 15, 1135

Margara J. (1982) In: Bases de la multiplication végétative. INRA, Versailles, France pp. 262

Monteuuis O. (1985) La multiplication végétative du séquoia géant en vue du clonage. Ann. AFOCEL 1984 139-171

Monteuuis O. (1987a) Microgreffage du séquoia géant. Ann. AFOCEL 1986 39-61

Monteuuis $O$. (1987b) In vitro meristem culture of juvenile and mature Sequoiadendron giganteum. Tree Physiol. 3, 265-272 
Monteuuis O. (1988) Aspects du clonage de séquoias géants jeunes et âgés. Ph.D. Thesis, Université Blaise-Pascal, Clermont-Ferrand, France

Monteuuis O. \& Bon M.C. (1986) Microbouturage du séquoia géant. Ann. AFOCEL 1985 4987

Monteuuis O. \& Gendraud M. (1987) Nucleotide and nucleic acid status in shoot tips from juvenile and mature clones of Sequoiadendron giganteum during rest and growth phases. Tree Physiol. 3, 257-263

Monteuuis O., Bon M.C. \& Berthon J.Y. (1987) Micropropagation aspects of Sequoiadendron giganteum juvenile and mature clones. Acta Hortic. 212, 489-197

Zobel B. \& Talbert J. (1984) In: Applied Forest Tree Improvement. John Wiley \& Sons; New York, pp. 505 